\title{
IDENTIFICATION OF PARAMETERS AND INVESTIGATION OF STABILITY OF THE MATHEMATICAL MODEL BIOSENSOR FOR MEASURING A-CHACONINE
}

\author{
Vasyl Martsenyuk ${ }^{1}$; Andrii Sverstiuk ${ }^{2}$; Sergei Dzyadevych ${ }^{3}$
}

\author{
${ }^{1}$ University of Bielsko-Biala, Bielsko-Biala, Poland \\ ${ }^{2}$ Ternopil National Medical University, Ternopil, Ukraine \\ ${ }^{3}$ Department of of Biomolecular Electronics, Institute of Molecular Biology and \\ Genetics, NAS of Ukraine, Kyiv, Ukraine
}

\begin{abstract}
Summary. The article is devoted to the problem of improving the existing mathematical and computational tools for obtaining and analyzing the results of numerical modeling in the design of biosensors. Parameters are identified in the work, stability is investigated and mathematical model is verified of a potentiometric biosensor based on the inverse inhibition of butyricolinesterase to determine $\alpha$-chaconin is substantiated. The mathematical model of the biosensor under study is represented by a system of seven linear differential equations that describe the dynamics of biochemical reactions during a complete cycle of measurement of $\alpha$-chaconine concentration. In this case, each of the differential equations describes the concentration of enzyme, substrate, inhibitor, product, enzyme-substrate, enzyme-inhibitory, enzyme-substrate-inhibitory complexes depending on time. A mathematical model of the biosensor for the determination of $\alpha$-chaconine is numerically solved using Wolfram Mathematica software. The initial parameters of the system are the initial concentrations of the enzyme, substrate and inhibitor $\left(5.8 \times 10^{-4} \mathrm{M}\right.$ butyricholinesterase, $1 \times 10^{-3} \mathrm{M}$ butyrylcholine chloride and $1 \times 10^{-6} ; 2 \times 10^{-6} ; 5 \times 10^{-6} ; 10 \times 10^{-6} \mathrm{M \alpha}$-chaconine, respectively), which are experimentally calculated. An existing potentiometric biosensor based on immobilized butyrylcholinesterase was used to verify the model and compare it with the experimental response. The forward and reverse rate constants of the enzymatic reactions are chosen so that the result of the numerical simulation is as consistent as possible with the experimental response of the biosensor under study. According to the results of the comparative analysis, the dependence of the deviation of the simulated and experimental responses of the biosensor to determine $\alpha$-chaconine is established. It is found that the absolute error does not exceed 0.045 conventional units. Based on the results of numerical simulation, it is concluded that the developed kinetic model of the potentiometric biosensor allows to adequately determine all the main components of the compartment components of biochemical reactions when measuring the concentration of $\alpha$-chaconine
\end{abstract}

Key words: mathematical model, biosensor, investigation of stability, $\alpha$-chaconine, numerical modeling

https://doi.org/10.33108/visnyk_tntu2019.04.101

Received 20.12.2019

Problem statement. Application of the results of mathematical and numerical simulation based on differential equations is a useful tool both for understanding biochemical processes and for making extensive use of optimization analytical characteristics of biosensors in their design.

Analysis of known research results. In recent years, much attention has been paid to the development and use of biosensors by researchers [1-10]. In [5-10], the main tasks related to the study of stability in biosensors are formulated. Over the last fifty years, many mathematical models have been developed and applied to optimize the performance of various biosensors [11-13]. In [14, 15], mathematical models for an ammetric electrode with an immobilized enzyme based on nonlinear differential equations are proposed, which describe Michaelis-Menten kinetics and diffusion, as well as a mathematical model of amperometric and potentiometric biosensors [16]. In these models, the homotopy perturbation method is used to solve the system of equations under stationary conditions. [17, 18] presented mathematical 
models of ammetric biosensors, which improved the sensitivity of the developed biosensors by changing the input parameters (reagent concentrations, kinetic constants, and membrane thickness). In these models, the finite-difference method is used to solve the equation system under both steady-state and non-steady-state conditions. The vast majority of mathematical models developed describe enzyme biosensors for direct substrate measurement. In addition, in recent years there has been a tendency to increase the development of biosensors based on inhibitory analysis $[19,20]$. To a greater extent, such biosensors are used in environmental monitoring for the detection of toxic substances such as pesticides, heavy metal ions, aflatoxins $[21,22]$. To date, quite a few mathematical models of biosensors of this type have been developed. Of these, one can distinguish a mathematical model of the glucose oxidase biosensor for the measurement of mercury ions [23]. In this model, a system of equations describing diffusion and enzymatic nonlinear reactions is related to Michaelis-Menten kinetics, which have been refined to account for irreversible inhibition.

This paper is devoted to the development of a mathematical model and the study of the stability of a previously developed butyrylcholinesterase biosensor based on ion-selective fieldeffect transistors (ISFET) for inhibitory measurement of $\alpha$-chaconine [24].

The question is very urgent, given that $\alpha$-chaconine is a very interesting biological object because of its toxicity and its concentration in potatoes as a food through which potatoes have a bitter taste. Measurement of the content of $\alpha$-chaconine in potatoes is performed when new varieties with reduced content are removed. In recent years, scientific research has been carried out, which results in the conclusion that mechanisms of resistance of potatoes to disease and insect action depend on the level of $\alpha$-chaconine. Other factors that affect the level of $\alpha$ chaconine and can cause a significant increase in its primary concentration are climatic changes, light effects, mechanical damage during potato harvesting and storage [25].

The goal of the work. The goal of the work is to ground, investigation of stability and verification of the mathematical model of the potentiometric biosensor for determination of $\alpha$ chaconine.

Setting objectives. Methods developed to determine total $\alpha$-chaconine content are based on the use of colorimetry, high performance liquid chromatography, thin layer and gas chromatography, radioimmunological analysis. These methods are characterized by high cost, long duration and complexity of sample preparation techniques. In order to optimize and modify existing methods for the analysis of harmful substances in potatoes, it is appropriate to create simple, inexpensive, highly sensitive methods for the measurement of $\alpha$-chaconine based on biosensors. At the same time, in order to save time and raw material resources (enzymes, substrates and inhibitors), it is advisable and economically advantageous to create and study adequate mathematical models of biosensors for the measurement of $\alpha$-chaconine with the possibility of numerical simulation.

\section{Results of the research.}

\section{Mathematical model of a potentiometric biosensor for determine $\alpha$-chaconin.}

For numerical simulation of mathematical model in the work we used previously developed biosensor for measurement of $\alpha$-chaconine [24].

As the bioselective element of the biosensor used the enzyme butyrylcholinesterase (BuChE). In a real experiment, $10^{-3} \mathrm{M}$ butyricoline chloride $(\mathrm{BuChCl})$ was used for working substrate concentration. As potentiometric transducers a pair of identical ion-selective p-type field-effect transistors with a sensitivity of $35-40 \mu \mathrm{A} / \mathrm{pH}$ placed on a single crystal has been used.

The differential equation system, which describes the mathematical model of the functioning of the developed biosensor for the measurement of $\alpha$-chaconine, was solved numerically by the $\mathrm{R}$ package. 
The program also built model responses from biosensors that are comparable to experimental data.

Using the literature data [24] for the inhibitory measurement of $\alpha$-chaconine using a BuChE-biosensor based on ion-selective field-effect transistors, the measurement process of the biosensor is attributed to a mixed type of inhibition, which can be schematically depicted in Figure 1.

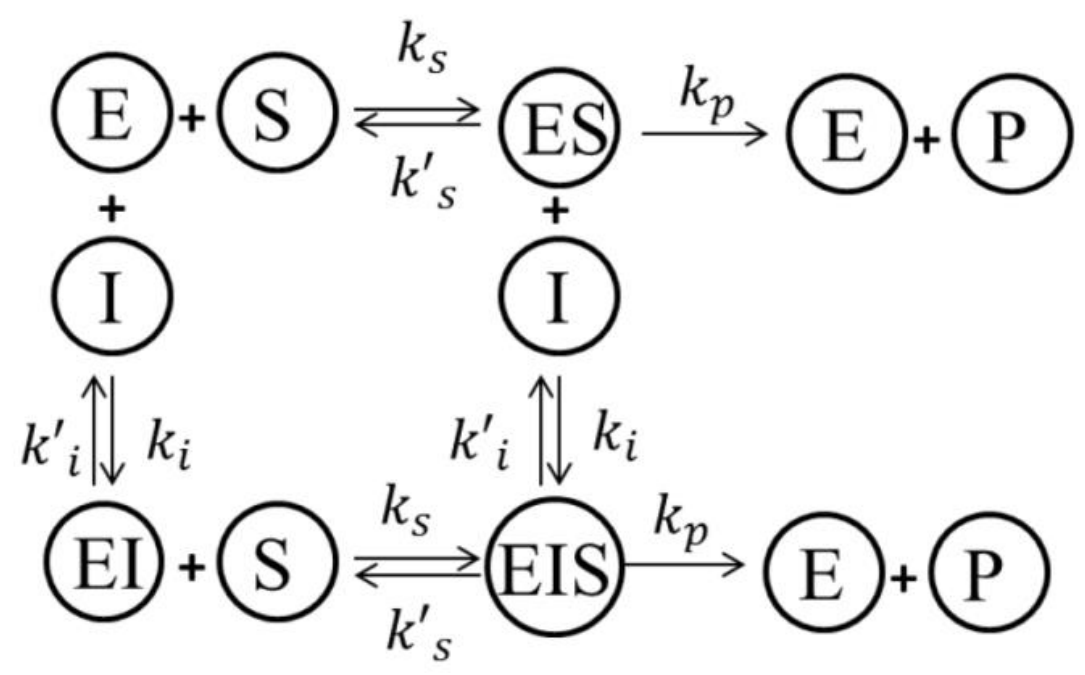

Figure 1. Schematic representation of the enzymatic reaction in a potentiometric biosensor based on BuChE-ISFET in the inhibitory measurement of $\alpha$-chaconine (E - enzyme, S - substrate, I - inhibitor)

In Figure $1 k_{s}$ and $k_{s}^{\prime}$ - the constants of the rate of forward and reverse reaction of the formation of the complex (ES), $k_{p}$ - the constant of the rate $v_{p}$ of formation of the product (P), $k_{i}$ and $k_{i}^{\prime}$ - the rate constants of the direct and reverse reaction of the formation of the complex (EI).

Mathematical model of a potentiometric biosensor based on the inverse inhibition of butyricolinesterase to determine $\alpha$-chaconin can be described by the following system of differential equations:

$$
\begin{gathered}
\frac{d n_{e}(t)}{d t}=-k_{s} n_{e}(t) n_{s}(t)-k_{i} n_{e}(t) n_{i}(t)+k_{s}^{\prime} n_{e s}(t)+k_{i}^{\prime} n_{e i}(t)+k_{p} n_{e s}(t) \\
\frac{d n_{s}(t)}{d t}=-k_{s} n_{e}(t) n_{s}(t)-\alpha k_{s} n_{e i}(t) n_{s}(t)+k_{s}^{\prime} n_{e s}(t)+\alpha k_{s}^{\prime} n_{e s i}(t) \\
\frac{d n_{e s}(t)}{d t}=k_{s} n_{e}(t) n_{s}(t)-k_{s}^{\prime} n_{e s}(t)-\alpha k_{i} n_{e s}(t) n_{i}(t)+\alpha k_{i}^{\prime} n_{e s i}(t)-k_{p} n_{e s}(t) \\
\frac{d n_{i}(t)}{d t}=-k_{i} n_{e}(t) n_{i}(t)-\alpha k_{i} n_{e s}(t) n_{i}(t)+k_{i}^{\prime} n_{e i}(t)+\alpha k_{i}^{\prime} n_{e s i}(t) \\
\frac{d n_{e i}(t)}{d t}=k_{i} n_{e}(t) n_{i}(t)-k_{i}^{\prime} n_{e i}(t)-\alpha k_{s} n_{e i}(t) n_{s}(t)+\alpha k_{s}^{\prime} n_{e s i}(t)
\end{gathered}
$$




$$
\begin{gathered}
\frac{d n_{e s i}(t)}{d t}=\alpha k_{i} n_{e s}(t) n_{i}(t)-\alpha k_{i}^{\prime} n_{e s i}(t)+\alpha k_{s} n_{e i}(t) n_{s}(t)-\alpha k_{s}^{\prime} n_{e s i}(t) \\
\frac{d n_{p}(t)}{d t}=k_{p} n_{e s}(t)-k_{w} n_{p}(t)
\end{gathered}
$$

where $k_{s}, k_{s}^{\prime}, k_{i}, k_{i}^{\prime}$ and $k_{p}$ - the corresponding rate constants of the reactions of complex formation; $k_{w}$ - washout constant; $\alpha$ - a constant whose numerical value determines the inhibition or activation of the enzyme; $n_{e}(t), n_{s}(t), n_{i}(t), n_{p}(t), n_{e s}(t), n_{e i}(t), n_{e s i}(t)-$ concentrations of enzyme, substrate, inhibitor, product, as well as enzyme-substrate, enzymeinhibitory and enzyme-substrate-inhibitory complexes, which change over time. The change in product concentration $n_{p}(t)$ time is directly proportional to the response of the biosensor.

The equations (1-7) describe the biochemical reactions taking place for concentrations of enzyme, substrate, inhibitor, product, enzyme-substrate, enzyme-inhibitory and enzymesubstrate-inhibitory. The first equation is considered for enzyme concentration $n_{e}(t)$. The first term on the right-hand side, $-k_{s} n_{e}(t) n_{s}(t)$, represents change of enzyme concentration $n_{e}(t)$ due to the reaction $\mathrm{E}+\mathrm{S} \rightarrow \mathrm{ES}$ going with a rate of $k_{s}$. The rate of this reaction is proportional to the enzyme concentration $n_{e}(t)$ and to the substrate concentration $n_{s}(t)$. The negative sign in this differential equation means that the process of ES formation results a decrease in the concentration of the enzyme $n_{e}(t)$.

The next term, $-k_{i} n_{e}(t) n_{i}(t)$, similarly to the first term, accounts for the reaction $\mathrm{E}+\mathrm{I} \rightarrow \mathrm{EI}$. The formation rate of EI complexes is proportional to the concentration of free (available) enzymes ne(t) and available inhibitors ni(t), and it leads to a decrease of ne(t), so it goes in negative. Dissociation of ES and EI molecules increases concentration of enzymes. It is taken into account by adding terms $+k_{s}^{\prime} n_{e s}(t)$ and $+k_{i}^{\prime} n_{e i}(t)$. Formation of product also releases enzyme molecules as $+k_{p} n_{e s}(t)$. All the other equations (2-7) are composed according to the following reactions in Figure 1.

Investigation of Steady States of the Biosensor Model.

Steady states of the system (1-7) can be found as a solution of the algebraic system:

$$
\begin{gathered}
-k_{s} n_{e}^{*} n_{s}^{*}-k_{i} n_{e}^{*} n_{i}^{*}+k_{s}^{\prime} n_{e s}^{*}+k_{i}^{\prime} n_{e i}^{*}+k_{p} n_{e s}^{*}=0 \\
-k_{s} n_{e}^{*} n_{s}^{*}-\alpha k_{s} n_{e i}^{*} n_{s}^{*}+k_{s}^{\prime} n_{e s}^{*}+\alpha k_{s}^{\prime} n_{e s i}^{*}=0 \\
k_{s} n_{e}^{*} n_{s}^{*}-k_{s}^{\prime} n_{e s}^{*}-\alpha k_{i} n_{e s}^{*} n_{i}^{*}+\alpha k_{i}^{\prime} n_{e s i}^{*}-k_{p} n_{e s}^{*}=0 \\
-k_{i} n_{e}^{*} n_{i}^{*}-\alpha k_{i} n_{e s}^{*} n_{i}^{*}+k_{i}^{\prime} n_{e i}^{*}+\alpha k_{i}^{\prime} n_{e s i}^{*}=0 \\
k_{i} n_{e}^{*} n_{i}^{*}-k_{i}^{\prime} n_{e i}^{*}-\alpha k_{s} n_{e i}^{*} n_{s}^{*}+\alpha k_{s}^{\prime} n_{e s i}^{*}=0
\end{gathered}
$$




$$
\begin{gathered}
\alpha k_{i} n_{e s}^{*} n_{i}^{*}-\alpha k_{i}^{\prime} n_{e s i}^{*}+\alpha k_{s} n_{e i}^{*} n_{s}^{*}-\alpha k_{s}^{\prime} n_{e s i}^{*}=0 \\
k_{p} n_{e s}^{*}-k_{w} n_{p}^{*}=0
\end{gathered}
$$

Clearly, the system $(8-14)$ has trivial solution $(0,0,0,0,0,0,0)^{\mathrm{T}}$. Nontrivial solutions $n^{*} \equiv\left(n_{e}^{*}, n_{s}^{*}, n_{e s}^{*}, n_{i}^{*}, n_{e i}^{*}, n_{e s i}^{*}, n_{p}^{*}\right)^{\mathrm{T}}$ can be calculated numerically.

Input parameters of the model (1-7), which were used in the experiment, are presented in the form of Table 1.

\section{Table 1}

Input parameters of the model biosensor for the measurement of $\alpha$-chaconine

\begin{tabular}{|c|c|c|}
\hline Model parameters & Numerical value & Unit of measurement \\
\hline$k_{s}$ & 1670 & $\mathrm{~L} /\left(\mathrm{mol}^{*} \mathrm{~s}\right)$ \\
\hline$k_{i}$ & 167000 & $\mathrm{~L} /\left(\mathrm{mol}^{*} \mathrm{~s}\right)$ \\
\hline$k_{s}^{\prime}$ & 0.4 & $1 / \mathrm{s}$ \\
\hline$k_{i}^{\prime}$ & 0.0003 & $1 / \mathrm{s}$ \\
\hline$k_{p}$ & 0.0008 & $1 / \mathrm{s}$ \\
\hline$k_{w}$ & 0.02 & $1 / \mathrm{s}$ \\
\hline$\alpha$ & 0.2 & $\mathrm{~mol} / \mathrm{L}$ \\
\hline$n_{e}(0)$ & $5.8 * 10^{-6}$ & $\mathrm{~mol} / \mathrm{L}$ \\
\hline$n_{s}(0)$ & 0.001 & $\mathrm{~mol} / \mathrm{L}$ \\
\hline$n_{i}(0)$ & $4 * 10^{-6}$ & \\
\hline
\end{tabular}

For the parameter values of Table 1 we get the steady $n^{*}$ state of the model (1-7) presented in the form of Table 2.

Table 2

Steady state of the model biosensor for the measurement of $\alpha$-chaconine

\begin{tabular}{|c|c|c|}
\hline Model parameters & Numerical values & Unit of measurement \\
\hline$n_{e}^{*}$ & $1,415 * 10^{-7}$ & $\mathrm{~mol} / \mathrm{L}$ \\
\hline$n_{s}^{*}$ & $4 * 10^{-3}$ & $\mathrm{~mol} / \mathrm{L}$ \\
\hline$n_{e s}^{*}$ & $1,129 * 10^{-6}$ & $\mathrm{~mol} / \mathrm{L}$ \\
\hline$n_{i}^{*}$ & $1,27 * 10^{-6}$ & $\mathrm{~mol} / \mathrm{L}$ \\
\hline$n_{e i}^{*}$ & $2,146 * 10^{-7}$ & $\mathrm{~mol} / \mathrm{L}$ \\
\hline$n_{e s i}^{*}$ & $1,715 * 10^{-6}$ & $\mathrm{~mol} / \mathrm{L}$ \\
\hline$n_{p}^{*}$ & $3,977 * 10^{-8}$ & $\mathrm{~mol} / \mathrm{L}$ \\
\hline
\end{tabular}


Stability research is fulfilled based on the linear model

$$
\frac{d x(t)}{d t}=\left.J(x(t))\right|_{x(t) \equiv n^{n}} x(t), x(t) \in R^{7}, t \geq 0,
$$

where $J(x(t))$ is the Jacobian of the system (1)-(7). Namely,

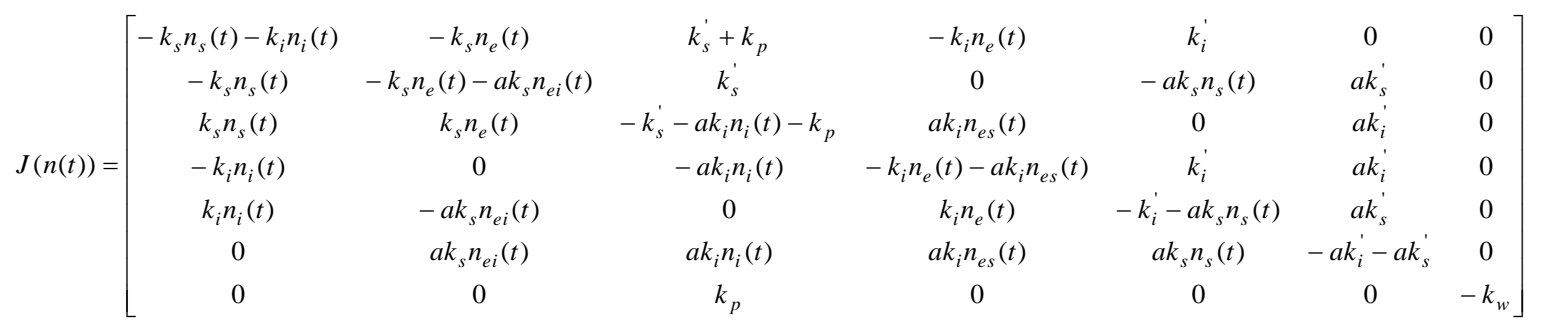

For the parameter values in Table 1 we get

$\left.J(n(t))\right|_{n(t) \equiv n^{*}}=\left[\begin{array}{ccccccc}-1.507978 \mathrm{e}+02 & -0.120773074 & 2.505000 \mathrm{e}+01 & -0.04830923 & 0.01670 & 0.00000 & 0.000 \\ -1.507948 \mathrm{e}+02 & -0.125109570 & 2.500000 \mathrm{e}+01 & 0.00000000 & -30.15896 & 5.00000 & 0.000 \\ 1.507948 \mathrm{e}+02 & 0.120773074 & -2.505060 \mathrm{e}+01 & 0.05816714 & 0.00000 & 0.00334 & 0.000 \\ -3.001462 \mathrm{e}-03 & 0.000000000 & -6.002924 \mathrm{e}-04 & -0.10647636 & 0.01670 & 0.00334 & 0.000 \\ 3.001462 \mathrm{e}-03 & -0.004336496 & 0.000000 \mathrm{e}+00 & 0.04830923 & -30.17566 & 5.00000 & 0.000 \\ 0.000000 \mathrm{e}+00 & 0.004336496 & 6.002924 \mathrm{e}-04 & 0.05816714 & 30.15896 & -5.00334 & 0.000 \\ 0.000000 \mathrm{e}+00 & 0.000000000 & 5.000000 \mathrm{e}-02 & 0.0000000 & 0.00000 & 0.00000 & -0.142\end{array}\right]$

Hence, we get all eigenvalues of $\left.J(n(t))\right|_{n(t) \equiv n^{*}}$ with negative real part, namely: $\lambda_{1}=-1.759682 \mathrm{e}+02, \quad \lambda_{2}=-3.517811 \mathrm{e}+01, \quad \lambda_{3}=-1.420000 \mathrm{e}-01, \quad \lambda_{4}=-1.116629 \mathrm{e}-01$, $\lambda_{5}=-9.815916 \mathrm{e}-04, \lambda_{6}=-3.437626 \mathrm{e}-05, \lambda_{7}=-3.865944 \mathrm{e}-15$.

Hence, using Hartman-Grobman theorem [26], we can conclude that the steady state $n^{*}$ of the system (1)-(7) at parameter values from Table 1 is locally asymptotically stable.

\section{chakonin.}

Numeric modeling of mathematical model of biosensor for measurement of $\alpha$ -

It is also taken into account that the system maintains a constant total concentration of the enzyme $\mathrm{E}_{0}$, so at any given time the sum of the concentrations of free (E) and bound (ES), (EI), (ESI) enzyme is equal to $(\mathrm{E})+(\mathrm{ES})+(\mathrm{EI})+(\mathrm{ESI})=\mathrm{E}_{0}$. To simulate the operation of the biosensor, the system described above was decoupled using package $\mathrm{R}$. The numerical simulation results are shown in Figure 2. 


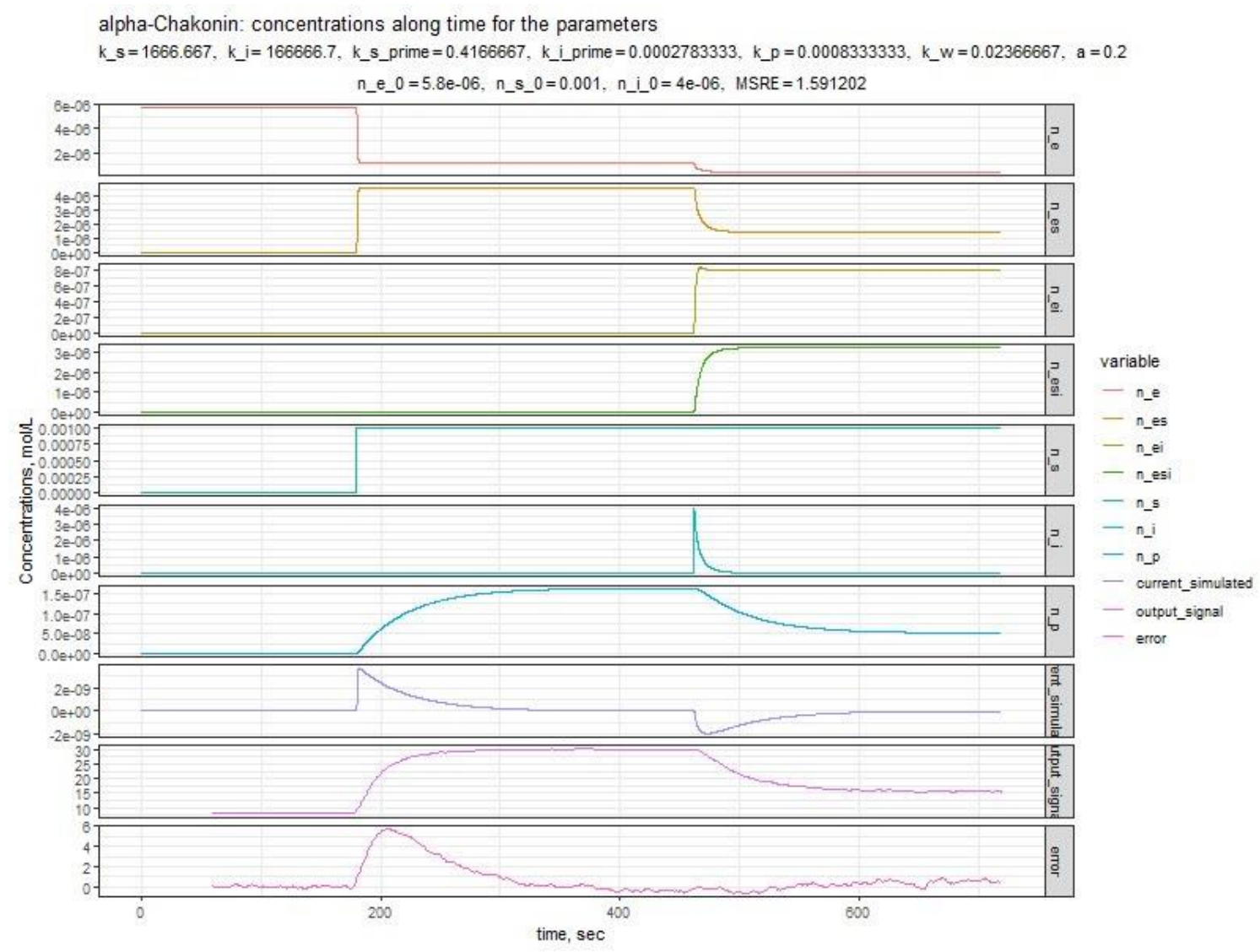

Figure 2. Numerical simulationof the enzymatic reaction in the BuCHE-ISFET membrane of the biosensor using kinetic equations (1-7) and the parameters presented in table 1 (n_e, n_es, n_ei, n_esi, n_s, n_i, n_p concentrations of enzyme, enzyme-substrate, enzyme-inhibitory, enzyme-substrate-inhibitory complexes, substrate, inhibitor, product, which change over time)

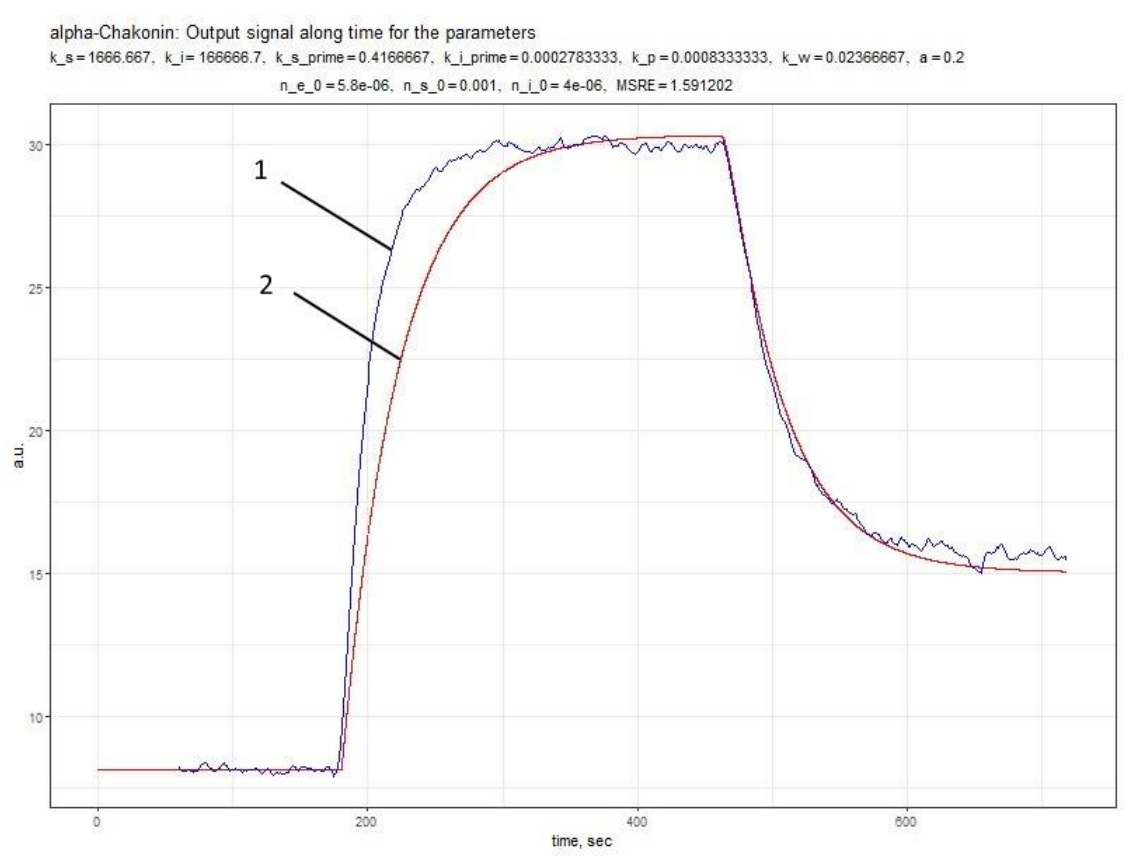

Figure 3. BuCHE-ISFET biosensor response: 1 - experimental; 2 - numerical simulation of the system (1-7) 
The squared error between experimental and simulated responses (Figure 3) of biosensor for measurement of $\alpha$-chaconine is 1.6 a.u.

At the zero stage of the simulation, the following initial conditions are set $n_{s}(0)=n_{i}(0)=n_{e s}(0)=n_{e i}(0)=n_{e s i}(0)=n_{p}(0)=0$, that is, when there is no substrate and inhibitor in the system, but only the initial enzyme concentration in the working membrane of the biosensor is entered. Under the given initial conditions and given parameters, there are solutions of the system. In the first stage, the system is decoupled under the initial conditions given by the zerophase system junctions and the initial substrate concentration is added to the working cell.

The response to the inhibitor is simulated by substituting the previous solutions and the concentration of the inhibitor known under the conditions of the experiment (Figure 4).

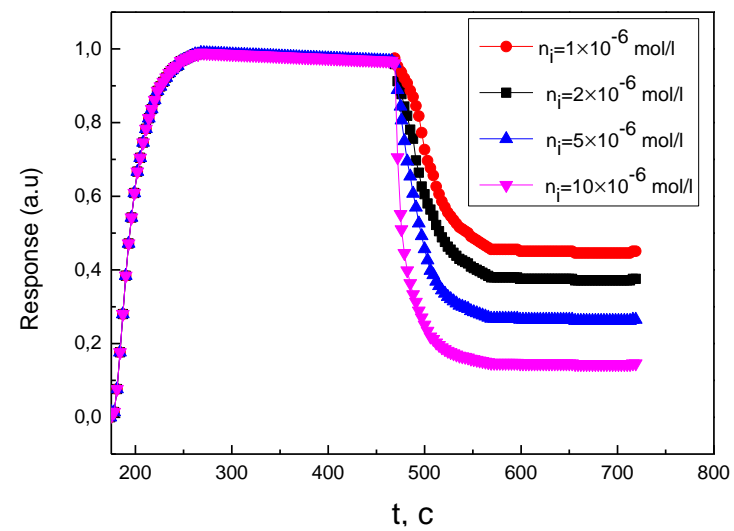

Figure 4. Numerical simulation of the response of the biosensor at different values of the concentration of inhibitor

In Figure 4 are presented results of numerical simulation of the response of the biosensor for the measurement of $\alpha$-chaconine at values of the concentration of inhibitor $1 * 10^{-6} \mathrm{~mol} / \mathrm{L}$, $2 * 10^{-6} \mathrm{~mol} / \mathrm{L}, 5 * 10^{-6} \mathrm{~mol} / \mathrm{L}, 10^{*} * 10^{-6} \mathrm{~mol} / \mathrm{L}$. It should be noted that the concentration of the inhibitor used are measuring levels of $\alpha$-chaconin. Analyzing the results of numerical simulation obtained in Figure 4 we can conclude that the higher the concentration of the inhibitor, the smaller the amplitude of the response of the investigation model of the biosensor. The simulated responses of the biosensor at different concentrations of the inhibitor are fully consistent with the principle of inhibition.

Conclusions. As a result of numerical simulation of the functioning of the biosensor, the concentrations of the enzyme, substrate, inhibitor, product, as well as enzyme-substrate, enzyme-inhibitory and enzyme-substrate-inhibitory complexes, which change over time, are obtained to determine $\alpha$-chaconine. The parameters of the model of the investigation biosensor are identified in the paper. The stability is investigated and mathematical model is verified of a potentiometric biosensor based on the inverse inhibition of butyricolinesterase to determine $\alpha$ chaconin is substantiated. The results obtained from the study of the stability of the biosensor model for measurement of $\alpha$-chaconine should be used for the design of new biosensors. The use of numerical simulation results will further minimize laboratory experiments with toxic and costly substances to select optimal concentrations of biosensor components to determine $\alpha$ chaconine. Numerical simulation was performed at initial concentrations of enzyme, substrate and inhibitor used in the experimental studies in the package $\mathrm{R}$. The physical content of the constants of the rate of formation of complexes was studied, on the basis of which the corresponding constants were selected so that the simulated response coincided as much as possible with the experimental response of the biosensor. The selected constants were used to model the responses of the biosensor to the addition of substrates and inhibitors. The results of numerical simulation are especially relevant when developing new biosensors and when dealing with toxic substance. 


\section{References}

1. Mosinska L., Fabisiak K., Paprocki K., Kowalska M., Popielarski P., Szybowicz M., Stasiak A. Diamond as a transducer material for the production of biosensors. Przemysl Chemiczny. 2013. Vol. 92. No. 6. P. 919-923.

2. Adley C. Past, present and future of sensors in food production. Foods. 2014. Vol. 3. No. 3. P. 491-510. Doi: 10.3390/foods3030491. https://doi.org/10.3390/foods3030491

3. Martsenyuk V. P., Klos-Witkowska A., Sverstiuk A. S. Study of classification of immunosensors from viewpoint of medical tasks. Medical informatics and engineering. 2018. № 1 (41). P. 13-19.

4. Martsenyuk V. P., Klos-Witkowska A., Sverstiuk A. S., Bihunyak T. V. On principles, methods and areas of medical and biological application of optical immunosensors. Medical informatics and engineering. 2018. № 2 (42). P. 28-36.

5. Martsenyuk V., Klos-Witkowska A., Sverstiuk A. Stability, bifurcation and transition to chaos in a model of immunosensor based on lattice differential equations with delay. Electronic Journal of Qualitative Theory of Differential Equations. 2018. No. 27. P. 1-31. https://doi.org/10.14232/ejqtde.2018.1.27

6. Martsenyuk V. P., Andrushchak I. Ye., Zinko P. M., Sverstiuk A. S. On Application of Latticed Differential Equations with a Delay for Immunosensor Modeling. Journal of Automation and Information Sciences. 2018. Vol. 50 (6). P. 55-65. https://doi.org/10.1615/JAutomatInfScien.v50.i6.50

7. Martsenyuk V. P., Sverstiuk A. S., Andrushchak I. Ye. Approach to the Study of Global Asymptotic Stability of Lattice Differential Equations with Delay for Modeling of Immunosensors. Journal of Automation and Information Sciences. 2019. Vol. 48 (8). P. 58-71. https://doi.org/10.1615/ JAutomatInfScien.v51.i2.70

8. Martsenyuk V., Sverstiuk A., Gvozdetska I. Using Differential Equations with Time Delay on a Hexagonal Lattice for Modeling Immunosensors. Cybernetics and Systems Analysis. 2019. Vol. 55 (4). P. 625-636. https://doi.org/10.1007/s10559-019-00171-2

9. Martsenyuk V. P., Klos-Witkowska A., Sverstiuk A. S. Stability, bifurcation and transition to chaos in a model of immunosensor based on lattice differential equations with delay. Electronic Journal of Qualitative Theory of Differential Equations. 2018. No. 27. P. 1-31. https://doi.org/10.14232/ejqtde.2018.1.27

10. Martsenyuk V. P., Andrushchak I. Ye., Zinko P. M., Sverstiuk A. S. On Application of Latticed Differential Equations with a Delay for Immunosensor Modeling. Journal of Automation and Information Sciences. Vol. 50 (6). 2018. P. 55-65. https://doi.org/10.1615/JAutomatInfScien.v50.i6.50

11. Mell L. D., Maloy J. T. A model for the amperometric enzyme electrode obtained through digital simulation and applied to the immobilized glucose oxidase system. Anal. Chem. 1975. Vol. 47. No. 2. P. 299-307. https://doi.org/10.1021/ac60352a006

12. Gajovic N., Warsinke A., Huang T., Schulmeister T., Scheller F. W. Characterization and Mathematical Modeling of a Bienzyme Electrode for 1-Malate with Cofactor Recycling. Analytical Chemistry. 1999. Vol. 71. No. 20. P. 4657-4662. https://doi.org/10.1021/ac9806355

13. Romero M. R., Baruzzi A. M., Garay F. Mathematical modeling and experimental results of a sandwichtype amperometric biosensor. Sensors Actuators, B Chemistry. 2012. Vol. 162. No. 1. P. $284-291$. https://doi.org/10.1016/j.snb.2011.12.079

14. Loghambal S., Rajendran L. Mathematical modeling of diffusion and kinetics in amperometric immobilized enzyme electrodes. Electrochimica Acta. 2010. Vol. 55. No. 18. P. 5230-5238. https://doi.org/10.1016/j.electacta.2010.04.050

15. Loghambal S., Rajendran L. Mathematical modeling in amperometric oxidase enzyme-membrane electrodes. Journal of Membrane Science. Vol. 373. No. 1-2. 2011. P. 20-28. https://doi.org/10.1016/ j.memsci.2011.02.033

16. Meena A., Rajendran L. Mathematical modeling of amperometric and potentiometric biosensors and system of non-linear equations - Homotopy perturbation approach. Journal of Electroanalytical Chemistry. 2010. Vol. 644. No. 1. P. 50-59. https://doi.org/10.1016/j.jelechem.2010.03.027

17. Ašeris V., Gaidamauskaite E., Kulys J., Baronas R. Modelling glucose dehydrogenase-based amperometric biosensor utilizing synergistic substrates conversion. Electrochimica Acta. 2014. Vol. 146. P. 752-758. https://doi.org/10.1016/j.electacta.2014.08.125

18. Ašeris V., Baronas R., Kulys J. Modelling the biosensor utilising parallel substrates conversion. Journal of Electroanalytical Chemistry. 2012. Vol. 685. P. 63-71. https://doi.org/10.1016/j.jelechem.2012.06.025

19. Arduini F., Amine A. Biosensors Based on Enzyme Inhibition. Advances in Biochemical Engineering. 2014. Vol. 140. P. 299-326. https://doi.org/10.1007/10_2013_224

20. Upadhyay L. S., Verma N. Enzyme Inhibition Based Biosensors: A Review. Analytical Letters. 2012. Vol. 46. P. 225-241. https://doi.org/10.1080/00032719.2012.713069

21. Stepurska K. V., Soldatkin O. O., Kucherenko I. S., Arkhypova V. M., Dzyadevych S. V., Soldatkin A. P. Feasibility of application of conductometric biosensor based on acetylcholinesterase for the inhibitory analysis of toxic compounds of different nature. Analytica Chimica Acta. 2015. Vol. 854. P. 161-168. https://doi.org/10.1016/j.aca.2014.11.027

22. Dhull V., Gahlaut A., Dilbaghi N., Hooda V. Acetylcholinesterase biosensors for electrochemical detection of organophosphorus compounds: A review. Biochemistry Research International. 2013. P. 1-18. https://doi.org/10.1155/2013/731501 
Identification of parameters and investigation of stability of the mathematical model biosensor for measuring $\alpha$ chaconine

23. Achi F., Bourouina-Bacha S., Bourouina M., Amine A. Mathematical model and numerical simulation of inhibition based biosensor for the detection of $\mathrm{Hg}(\mathrm{II})$. Sensors \& Actuators, B: Chemical. 2015. Vol. 207. P. 413-423. https://doi.org/10.1016/j.snb.2014.10.033

24. Arkhypova V. N, Dzyadevych S. V., Soldatkin A. P., El'skaya A. V., Martelet C., Jaffrezic-Renault N. Development and optimisation of biosensors based on $\mathrm{pH}$-sensitive field effect transistor and cholinesterase for sensitive detection of solanaceous glycoalkaloids. Biosensors \& Bioelectronics. 2003. Vol. 18. P. 1047-1053. https://doi.org/10.1016/S0956-5663(02)00222-1

25. Arkhypova V. N., Dzyadevych S. V., Soldatkin A. P., Korpan Y. I., El'skaya A. V., Gravoueille J.-M., Martelet C., Jaffrezic-Renault N. Application of enzyme field effect transistors for fast detection of total glycoalkaloids content in potatoes. Sensors and Actuators B. 2004. Vol. 103. P. 416-422. https://doi.org/ 10.1016/j.snb.2004.04.070

26. Arrowsmith D. K., Place C. M. The Linearization Theorem. Dynamical Systems: Differential Equations, Maps, and Chaotic Behaviour. London: Chapman \& Hall. 1992. P. 77-81.

\section{Список використаної літератури}

1. Mosinska L., Fabisiak K., Paprocki K., Kowalska M., Popielarski P., Szybowicz M., Stasiak A. Diamond as a transducer material for the production of biosensors. Przemysl Chemiczny. 2013. Vol. 92. No. 6. P. 919-923.

2. Adley C. Past, present and future of sensors in food production. Foods. 2014. Vol. 3. No. 3. P. 491-510. Doi: 10.3390/foods3030491. https://doi.org/10.3390/foods3030491

3. Martsenyuk V. P., Klos-Witkowska A., Sverstiuk A. S. Study of classification of immunosensors from viewpoint of medical tasks. Medical informatics and engineering. 2018. № 1 (41). P. 13-19.

4. Martsenyuk V. P., Klos-Witkowska A., Sverstiuk A. S., Bihunyak T. V. On principles, methods and areas of medical and biological application of optical immunosensors. Medical informatics and engineering. 2018. № 2 (42). P. 28-36.

5. Martsenyuk V., Klos-Witkowska A., Sverstiuk A. Stability, bifurcation and transition to chaos in a model of immunosensor based on lattice differential equations with delay. Electronic Journal of Qualitative Theory of Differential Equations. 2018. No. 27. P. 1-31. https://doi.org/10.14232/ejqtde.2018.1.27

6. Martsenyuk V. P., Andrushchak I. Ye., Zinko P. M., Sverstiuk A. S. On Application of Latticed Differential Equations with a Delay for Immunosensor Modeling. Journal of Automation and Information Sciences. 2018. Vol. 50 (6). P. 55-65. https://doi.org/10.1615/JAutomatInfScien.v50.i6.50

7. Martsenyuk V. P., Sverstiuk A. S., Andrushchak I. Ye. Approach to the Study of Global Asymptotic Stability of Lattice Differential Equations with Delay for Modeling of Immunosensors. Journal of Automation and Information Sciences. 2019. Vol. 48 (8). P. 58-71. https://doi.org/10.1615/ JAutomatInfScien.v51.i2.70

8. Martsenyuk V., Sverstiuk A., Gvozdetska I. Using Differential Equations with Time Delay on a Hexagonal Lattice for Modeling Immunosensors. Cybernetics and Systems Analysis. 2019. Vol. 55 (4). P. 625-636. https://doi.org/10.1007/s10559-019-00171-2

9. Martsenyuk V. P., Klos-Witkowska A., Sverstiuk A. S. Stability, bifurcation and transition to chaos in a model of immunosensor based on lattice differential equations with delay. Electronic Journal of Qualitative Theory of Differential Equations. 2018. No. 27. P. 1-31. https://doi.org/10.14232/ejqtde.2018.1.27

10. Martsenyuk V. P., Andrushchak I. Ye., Zinko P. M., Sverstiuk A. S. On Application of Latticed Differential Equations with a Delay for Immunosensor Modeling. Journal of Automation and Information Sciences. Vol. 50 (6). 2018. P. 55-65. https://doi.org/10.1615/JAutomatInfScien.v50.i6.50

11. Mell L. D., Maloy J. T. A model for the amperometric enzyme electrode obtained through digital simulation and applied to the immobilized glucose oxidase system. Anal. Chem. 1975. Vol. 47. No. 2. P. 299-307. https://doi.org/10.1021/ac60352a006

12. Gajovic N., Warsinke A., Huang T., Schulmeister T., Scheller F. W. Characterization and Mathematical Modeling of a Bienzyme Electrode for 1-Malate with Cofactor Recycling. Analytical Chemistry. 1999. Vol. 71. No. 20. P. 4657-4662. https://doi.org/10.1021/ac9806355

13. Romero M. R., Baruzzi A. M., Garay F. Mathematical modeling and experimental results of a sandwichtype amperometric biosensor. Sensors Actuators, B Chemistry. 2012. Vol. 162. No. 1. P. $284-291$. https://doi.org/10.1016/j.snb.2011.12.079

14. Loghambal S., Rajendran L. Mathematical modeling of diffusion and kinetics in amperometric immobilized enzyme electrodes. Electrochimica Acta. 2010. Vol. 55. No. 18. P. 5230-5238. https://doi.org/10.1016/j.electacta.2010.04.050

15. Loghambal S., Rajendran L. Mathematical modeling in amperometric oxidase enzyme-membrane electrodes. Journal of Membrane Science. Vol. 373. No. 1-2. 2011. P. 20-28. https://doi.org/10.1016/ j.memsci.2011.02.033

16. Meena A., Rajendran L. Mathematical modeling of amperometric and potentiometric biosensors and system of non-linear equations - Homotopy perturbation approach. Journal of Electroanalytical Chemistry. 2010. Vol. 644. No. 1. P. 50-59. https://doi.org/10.1016/j.jelechem.2010.03.027

17. Ašeris V., Gaidamauskaitė E., Kulys J., Baronas R. Modelling glucose dehydrogenase-based amperometric biosensor utilizing synergistic substrates conversion. Electrochimica Acta. 2014. Vol. 146. P. 752-758. https://doi.org/10.1016/j.electacta.2014.08.125

18. Ašeris V., Baronas R., Kulys J. Modelling the biosensor utilising parallel substrates conversion. Journal of Electroanalytical Chemistry. 2012. Vol. 685. P. 63-71. https://doi.org/10.1016/j.jelechem.2012.06.025 
19. Arduini F., Amine A. Biosensors Based on Enzyme Inhibition. Advances in Biochemical Engineering. 2014. Vol. 140. P. 299-326. https://doi.org/10.1007/10_2013_224

20. Upadhyay L. S., Verma N. Enzyme Inhibition Based Biosensors: A Review. Analytical Letters. 2012. Vol. 46. P. 225-241. https://doi.org/10.1080/00032719.2012.713069

21. Stepurska K. V., Soldatkin O. O., Kucherenko I. S., Arkhypova V. M., Dzyadevych S. V., Soldatkin A. P. Feasibility of application of conductometric biosensor based on acetylcholinesterase for the inhibitory analysis of toxic compounds of different nature. Analytica Chimica Acta. 2015. Vol. 854. P. 161-168. https://doi.org/10.1016/j.aca.2014.11.027

22. Dhull V., Gahlaut A., Dilbaghi N., Hooda V. Acetylcholinesterase biosensors for electrochemical detection of organophosphorus compounds: A review. Biochemistry Research International. 2013. P. 1-18. https://doi.org/10.1155/2013/731501

23. Achi F., Bourouina-Bacha S., Bourouina M., Amine A. Mathematical model and numerical simulation of inhibition based biosensor for the detection of $\mathrm{Hg}(\mathrm{II})$. Sensors \& Actuators, B: Chemical. 2015. Vol. 207. P. 413-423. https://doi.org/10.1016/j.snb.2014.10.033

24. Arkhypova V. N, Dzyadevych S. V., Soldatkin A. P., El'skaya A. V., Martelet C., Jaffrezic-Renault N. Development and optimisation of biosensors based on $\mathrm{pH}$-sensitive field effect transistor and cholinesterase for sensitive detection of solanaceous glycoalkaloids. Biosensors \& Bioelectronics. 2003. Vol. 18. P. 1047-1053. https://doi.org/10.1016/S0956-5663(02)00222-1

25. Arkhypova V. N., Dzyadevych S. V., Soldatkin A. P., Korpan Y. I., El'skaya A. V., Gravoueille J.-M., Martelet C., Jaffrezic-Renault N. Application of enzyme field effect transistors for fast detection of total glycoalkaloids content in potatoes. Sensors and Actuators B. 2004. Vol. 103. P. 416-422. https://doi.org/ 10.1016/j.snb.2004.04.070

26. Arrowsmith D. K., Place C. M. The Linearization Theorem. Dynamical Systems: Differential Equations, Maps, and Chaotic Behaviour. London: Chapman \& Hall. 1992. P. 77-81.

\title{
УДК 004:94:53:616-073
}

\section{ІДЕНТИФІКАЦІЯ ПАРАМЕТРІВ ТА ДОСЛІДЖЕННЯ СТІЙКОСТІ МАТЕМАТИЧНОЇ МОДЕЛІ БІОСЕНСОРУ ДЛЯ ВИЗНАЧЕННЯ $\alpha$-ЧАКОНІНУ}

\section{Василь Марценюк'; Андрій Сверстюк²; Сергій Дзядевич ${ }^{3}$}

\author{
${ }^{1}$ Університет в Бєльсько-Бялій, Бєльсько-Бяла, Польщу \\ ${ }^{2}$ Тернопільський національний медичний університет \\ імені І. Я. Горбачевського, Тернопіль, Украӥна \\ ${ }^{3}$ Інститут молекулярної біології та генетики НАН України, Київ, Украӥна
}

\begin{abstract}
Резюме. Присвячено проблемі вдосконалення існуючих математичних і обчислювальних засобів для отримання та аналізу результатів чисельного моделювання при проектуванні біосенсорів. Ідентифіковано параметри, досліджено стійкість та проведено верифікацію математичної моделі потенціометричного біосенсору на основі зворотного інгібування бутирихолінестерази для визначення $\alpha$ чаконіну. Математична модель досліджуваного біосенсору представлена системою семи лінійних диференціальних рівнянь, які описують динаміку біохімічних реакцій під час повного циклу вимірювання концентрації $\alpha$-чаконіну. При изьому кожне із диференціальних рівнянь описує концентрації ферменту, субстрату, інгібітора, продукту, фермент-субстратного, фермент-інгібіторного, фермент-субстратінгібіторного комплексів залежно від часу. Математична модель біосенсора для визначення $\alpha$-чаконіну розв'язана чисельно за допомогою пакета $R$. Вхідними параметрами системи є початкові концентрації ферменту, субстрату та інгібітора $\left(5,8 \times 10^{-4}\right.$ М бутирихолінестерази, $1 \times 10^{-3}$ М бутирихолін хлориду та $1 \times 10^{-6} ; 2 \times 10^{-6} ; 5 \times 10^{-6} ; 10 \times 10^{-6} \mathrm{M}$-чаконіну відповідно), які експериментально розраховані. Для верифікації моделі та порівняння $з$ експериментальним відгуком використано існуючий потенціометричний біосенсор на основі іммобілізованої бутирихолінестерази. Прямі та зворотні константи швидкостей ферментативних реакцій підібрані таким чином, щзоб результат чисельного моделювання максимально відповідав експериментальному відгуку досліджуваного біосенсора. 3 а результатами порівняльного аналізу встановлено залежність відхилення змодельованого та експериментального відгуків біосенсора для визначення $\alpha$-чаконіну. Встановлено, щчо абсолютна похибка не перевищує 0,045 ум.од. На основі отриманих результатів чисельного моделювання зроблено висновок, що розроблена кінетична модель потенціометричного біосенсора дає змогу адекватно визначати усі основні складові компартментних компонент біохімічних реакцій при вимірюванні концентрації $\alpha$-чаконіну.
\end{abstract}

Ключові слова: математична модель, біосенсор, дослідження стійкості $\alpha$-чаконін, чисельне моделювання. 